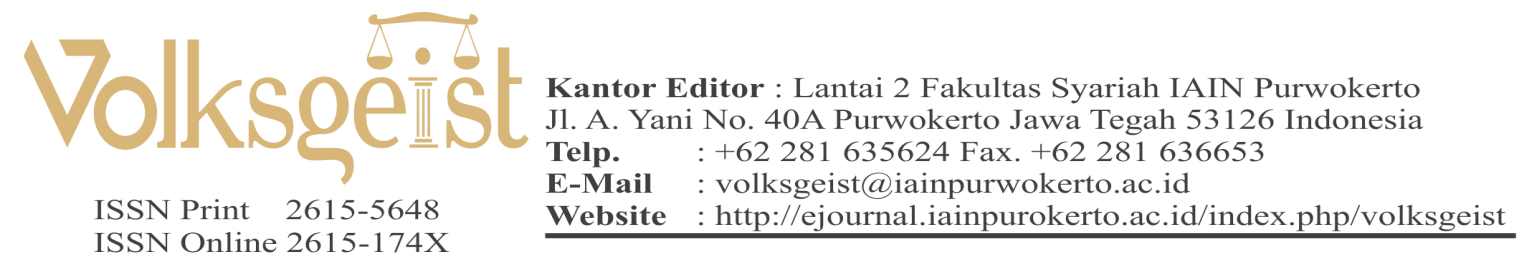

\title{
Legalitas Impor Vaksin Covid-19 Perspektif Maqashid Syariah
}

\author{
Allina Mustaufiatin Ni'mah, ${ }^{1}$ Syufa'at \\ ${ }^{1}$ Pascasarjana UIN Prof. Kiai Haji Saifudin Zuhri Purwokerto \\ Email: allinamn22@gmail.com_
}

\begin{abstract}
Abstrak
Artikel ini bertujuan untuk mengetahui legalitas impor vaksin Covid-19 oleh Kementrian Kesehatan perspektif maqasid syariah. Artikel ini adalah penelitian pustaka dengan menggunakan kajian pustaka sebagai sumber hukum primer. Hasil dari penelitian menunjukan bahwa legalitas impor vaksin Covid-19 dalam maqashid syariah bertujuan untuk masyarakat percaya dan patuh terhadap program vaksinasi pemerintah guna mengurangi penyebaran virus Covid-19 dan angka kematian untuk melindungi jiwa (hifz al-nafs) masyarakat Indonesia. Legalitas impor vaksin Covid-19 menggunakan mekanisme akad salam diketahui ada syarat yang belum terpenuhi yaitu syarat spesifikasi objek. Spesifikasi objek dalam hal ini meliputi jaminan kehalalan, thayib dan jaminan keamanan produk vaksin Covid-19. Oleh karena itu, proses audit dari pihak BPOM dan sertifikasi halal dari MUI dijadikan dasar legalitas impor vaksin Covid-19 terpenuhinya syarat spesikasi barang. Apabila dalam proses impor vaksin Covid-19 terdapat force majeur maka perjanjian dapat diperbaharui atau dibatalkan dan jika terdapat perselisihan dapat diselesaikan melalui arbitrase.
\end{abstract}

Kata Kunci: impor, akad salam, vaksin Covid-19

\begin{abstract}
This article aims to determine the legality of importing Covid-19 vaccines by the Ministry of Health from sharia maqasid perspective. This article is a literature study using literature review as the primary legal source. The results of the study show that the legality of importing Covid-19 vaccines in maqshid sharia aims to make people believe and obey the government's vaccination program to decrease the spread of the Covid-19 virus and the death rate to protect the lives (hifz al-nafs) of the Indonesian people. The legality of importing the Covid-19 vaccine using salam contract mechanism is known to have unfulfilled conditions, namely the object specification requirements. The object specifications in this case include halal assurance, thayib and safety guarantees of Covid-19 vaccine products. Therefore, the audit process from BPOM and halal certification from MUI used as the basis for the legality of importing the Covid-19 vaccine, make the object specification requirements fulfilled. If in the process of importing the Covid-19 vaccine there is force majeure, the agreement can be renewed or canceled and if there is a dispute, it can be resolved through arbitration.
\end{abstract}

Keywords: import, akad salam, vaccine Covid-19 


\section{Sejarah Artikel}

Dikirim: 02 April 2021

Direview: 08 Juni 2021

Diterima: 16 Juni 2021

Diterbitkan: 17 Juni 2021

\section{PENDAHULUAN}

Satu tahun pandemi Covid-19 mengakibatkan manusia hidup dalam ketidakpastian dan mempengaruhi kesejahteraanya dalam bidang spiritual (hifz al-din), jiwa (hifz al$n a f s$ ), pendidikan (hifz al-'aql), ekonomi (hifz al-mōl), reproduksi (hifz al-nasl). Ancaman terhadap jiwa justru paling menderita akibat Covid-19, isolasi, pudarnya cita-cita dan berkurangnya lapangan pekerjaan. Langkah cepat diambil pemerintah untuk mencegah dan menghentikan penyebaran Covid-19 dengan menerapkan protokol kesehatan, mengimpor dan memproduksi vaksin Covid-19 dengan jaminan legalitas dari MUI dan izin produksi dari BPOM.

Vaksin Covid-19 merupakan salah satu bentuk upaya mencegah dan meghentikan penyebaran coronavirus disease 2019 (Covid-19). Covid-19merupakan varian baru dari novel corona virus yang menyebabkan penyakit pada manusia maupun hewan. Penularan Covid-19 tergolong sangat cepat, karena dengan menghirup atau masuk melalui mata dan mulut akan bersirkulasi dalam tubuh manusia dan menimbulkan gejala hingga penyakit serius. Kasus positifCovid-19 menurut Tonang Dwi Ardyanto ahli patologi klinis tidak selalu menunjukan gejala. Seorang dinyatakan positif ada tiga kelompok yaitu:

1. Murni tanpa gejala (asimptomatik).

2. Pre-simptomatik: saat dinyatakan positif pasien tidak bergejala, tetapi beberapa hari kemudian muncul gejala.

3. Simptomatik: saat dinyatakan positif memang sudah ada gejala. ${ }^{1}$

\footnotetext{
1 S.S Kurniawan, "Terjangkit virus corona tanpa
}

Dari tiga kelompok orang terindikasi posiitf Covid-19 dengan gejala dapat dikenali gejalagejala yang menunjukan terpapar Covid-19. Sebagaimana gejala pada flu biasa, Covid-19 mempunyai gejala yang sama hanya saja yang membedakan seperti sesak nafas, kelelahan, batuk, sakit kepala, nyeri dada dan nyeri otot, sulit berkonsentrasi, demam, hilangnya indra penciuman dan pengecap, radang mata dan mukosa. Pengobatan untuk pasien positif Covid-19 untuk sampai sekarang belum ada secara spesifik, manusia yang terinfeksi dapat diobati dengan obat-obatan suportif yang mampu menekan timbulnya gejala klinis. Oleh karena itu, untuk menekan angka kasus positif Covid-19 dapat dilakukan pencegahanpencehagan diri, dari kementerian kesehatan Indonesia memberi edukasi terkait pencegahan diri yaitu:

1. Menjaga kesehatan dan kebugaran tubuh supaya imun atau kekebalan tubuh meningkat.

2. Makan dengan gizi baik dan konsumsi vitamin.

3. Mencuci tangan dengan sabun cuci tangan lalu bilas dengan air bersih secara benar atau menggunakan handsanitizer.

4. Menjaga jarak minimal 1 meter, karena jika kurang dari 1 meter dapat menularkan virus melalui droplet dari orang yang kemungkinan terkena Covid-19.

5. Menggunakan masker dengan benar, yaitu menutup bagian mulut dan hidung saat keluar dari rumah.

6. Hindari menyentuh hidung, mulut atau mata. Karena apabila tangan terkontaminasi virus lalu menyentuh hidung, mata atau mulut maka dengan mudah virus masuk ke dalam tubuh.

gejala, benar-benar tak merasakan gejala?," September 14, 2020, https://kesehatan.kontan.co.id/news/terjangkitvirus-corona-tanpa-gejala-benar-benar-tak-merasakangejala. 
7. Buanglah masker atau tissue yang telah digunakan dengan benar ke tempat sampah.

8. Hindari tempat umum atau kerumunan, dan tetap di rumah.

Upaya pencegahan diri belum mampu menekan kenaikan angka penyebaran Covid-19 sehingga membuat para ilmuwan virologi untuk menciptakan vaksin Covid-19. Jackson beserta ilmuwan lain melaporkan dalam Journal temuan awal dari uji coba fase 1 untuk mengevaluasi keamanan dan imunogenisitas vaksin mRNA SARS-CoV-2. Fase 1 melibatkan 45 orang dewasa sehat, usia 18 hingga 55 tahun, yang ditugaskan untuk menerima kandidat vaksin pada satu dari tiga tingkat dosis $(25 \mu \mathrm{g}, 100 \mu \mathrm{g}$, atau $250 \mu \mathrm{g}$ ) diberikan sebagai dua vaksinasi dengan jarak 28 hari. Temuan awal ini mewakili yang pertama dari tiga laporan data dari studi fase 1 dari kandidat vaksin ini, laporan kedua termasuk data serupa dari orang dewasa yang berusia lebih dari 55 tahun dan laporan akhir yang merangkum keamanan dan daya tahan imun.

A vaccine is urgently neededto prevent Covid-19 and thereby stem complications and deaths resulting from transmission of the disease. Jackson et al. now report in the Journal preliminary findings from a phase 1 trial to evaluate the safety and immunogenicity of an mRNA SARS-CoV-2 vaccine. 3 Phase 1 involves 45 healthyadults, 18 to 55 years of age, who were assignedto receive the candidate vaccine at one of three dose levels $(25 \mu \mathrm{g}, 100$ $\mu \mathrm{g}$, or $250 \mu \mathrm{g}$ ) given as two vaccinations 28 days apart. These preliminary findings represent the first of three reports of data from a phase 1 study of this candidate vaccine; a second report including similar data from adults older than 55 years of age and a finalreport summarizing the safety and durability of immun. ${ }^{2}$

${ }^{2}$ Penny M. Heaton, "The Covid-19 VaccineDevelopment Multiverse," The New England Journal of Medicine 383, no. 20 (November 12, 2020): 1986-88, https://doi.org/10.1056/NEJMe2025111.
Indonesia mempunyai wilayah yang luas, yang terdiri dari beribu-ribu pulau yang besar dan kecil, serta masyarakat yang pluralistik dari segi agama, budaya dan ras atau suku, sehingga pemerintah pusat tidak mungkin dapat menyelenggarakan pemerintahan dengan baik, apabila segala sesuatunya diputuskan dan dilaksanakan sendiri. ${ }^{3}$ Oleh karena itu, dengan negara angka positif Covid-19 yang tinggi dan belum dapat memporduksi vaksin secara mandiri. Maka Indonesia mengimpor vaksin bahan baku vaksin maupun vaksin siap pakai di perusahaan luar negeri. Bila ditinjau dari kacamata hukum ekonomi syariah, legalitas impor vaksin Covid-19 termasuk dalam akad jual beli salam, karena Indonesia dalam pembelian vaksin dengan sistem pesan produk terlebih dahulu. Ketentuan transakasi akad jual beli salam dalam Islam harus memenuhi rukun dan syarat-syaratnya, dimana salah satu syaratnya adalah objek yang diperjual-belikan halal. Legalitas impor vaksin Covid-19 bagian dari maqashid syariah yaitu untuk mengurangi angka kematian akibat Covid-19 dan menekan angka positif dengan melindungi jiwa (hifz alnafs).

Berkaitan dengan artikel ini, tentunya sudah ada beberapa artikel terdahulu yang telah membahasnya. Diantaranya artikel program vaksinasi dalam perspektif Islam adalah mubah, dimana halal bagi yang mengikuti vaksin dan tidak berdosa secara syariat bagi yang menolaknya. ${ }^{4}$ Artikel lain produksi vaksin meningitis dalam perspektif maqashid membahas tentang produksi vaksin meningitis

3 Hariyanto Hariyanto, "Hubungan Kewenangan Antara Pemerintah Pusat Dan Pemerintah Daerah Berdasarkan Negara Kesatuan Republik Indonesia," Volksgeist: Jurnal Ilmu Hukum Dan Konstitusi 3, no. 2 (December 29, 2020): 105, https://doi.org/10.24090/ volksgeist.v3i2.4184.

4 Muhammad Mahmud Nasution, "Vaksinasi Dalam Perspektif Islam," Forum Paedagogik 9, no. 2 (2018): 61-70, https://doi.org/10.24952/paedagogik. v10i2.2818. 
yang digunakan oleh jamaah haji dan umrah bertujuan untuk kemaslahatan yaitu mencegah diri dari kerusakan atau bahaya dimana hal ini termasuk dalam kategori maslahah daruriyat melindungi jiwa (hifz al-nafs). ${ }^{5}$ Artikel lain vaksinasi pada dasarnya merupakan hal yang diperbolehkan, namun dalam konteks penjgaan terhadap kesehatan masyarakat secara umum vaksinasi menjadi wajib, baik kandungan vaksin mengandung halal maupun haram. Vaksin yang mengandung haram tidak lepas dari rukhsah dan darurat karena kesehatan masyarakat dalam wabah tentu merupakan kebutuhan yang mendesak. Mengingat vaksinasi efektif ketika dilakukan secara masal untuk pencegahan virus dan tingkat penguatan hukum dalam hal ini didasarkan pada qawaid fiqhiyah yang ada dan salah satu tujuan dalam hal menjaga kewajiban dan melindungi jiwa (hifz al-nafs). ${ }^{6}$

Berdasarkan hal tersebut di atas, maka artikeliniberbeda dengan artikel-artikel tersebut, karena artikel ini menguraikan legalitas hukum impor vaksin Covid-19 di Indonesia ditinjau dari maqashid syariah. Artikel ini menggunakan penelitian kepustakaan dan mengintergrasikan ide-ide dalam menganalisis data penelitiaan untuk membuat kesimpulan. ${ }^{7}$ Analisis data penelitian kemudian dideskripsikan secara khusus terkait pengadaan vaksin Covid-19 yang ditetapkan di Indonesia sesuai atau tidak impor vaksin Covid-19 dengan ketentuan hukum ekonomi syariah dan maqashid syariah.

5 Anwar Hafidzi, "Penggunaan Vaksin: Antara Legalitas Dan Formalitas Perspektif Maqashid AlSyariah," Yudisia : Jurnal Pemikiran Hukum Dan Hukum Islam 11, no. 2 (Desember 2020).

6 "Vaccination from the Perspective of Islamic Legal Maxim," International Journal of Academic Research in Business and Social Sciences 7, no. 12 (2017).

7 Iqbal Hasan, Analisis Data Penelitian Dengan Statistik (Jakarta: PT. Bumi Aksara, 2006), 87.

\section{PEMBAHASAN}

\section{Akad Salam Vaksin Covid-19 Di Indonesia}

1. Definisi akad jual beli salam

Menurut kompilasi Hukum Islam (KHES) salam adalah jasa pembiayaan yang berkaitan dengan jual beli yang pembayarannya dilakukan dengan pemesanan barang. ${ }^{8}$ Para ulama Syafi'iyah dan Hanabilah mendefinisikan akad salam sebagai akad atas sesuatu yang dijelaskan sifatnya dalam tanggungan mendatang dengan imbalan harga yang diserahkan dalam majelis akad, ulama Malikiyah mendefinisikannya sebagai sebuah transaksi jual beli di mana modal diserahkan terlebih dahulu, sedangkan barang yang dibeli diserahkan setelah tenggat waktu tertentu. ${ }^{9}$ Akad jual beli salam adalah dengan sistem pesan suatu barang dengan tanggungan mendatang atau pembayaran mendatang ketika penyerahan barang dalam majeli sakad

2. Dasar hukum akad jual beli salam

Landasan kebolehan akad jual beli salam terdapat dalil dalam al-Qur'an surat al-Baqarah ayat 282: "Hai orangorang yang beriman, apabila kamu bermu'amalah tidak secara tunai untuk waktu yang ditentukan, hendaklah kamu menuliskannya. Dan hendaklah seorang. ${ }^{10}$

Selain didasarkan pada nas al-qur'an juga dalam hadis Nabi riwayat Bukhari nomor 2240: "Suatu saat Rasulullah datang di Madinah, disana para penduduk Madinah sudah mempraktikkan salam pada kurma yang berumur dua tahun atau tiga tahun. Maka Rasulullah berkata:

${ }^{8}$ Kompilas Hukum Ekonomi Syari'ah (Jakarta: Mahkamah Agung RI, 2011), 14, https://perpustakaan. mahkamahagung.go.id/assets/resource/ebook/02.pdf.

${ }^{9}$ Wahbah Az-Zuhaili, Fiqih Islam Wa Adillatuhu (Jakarta: Gema Insani, 2011), 230.

${ }^{10} \mathrm{Ma}$ 'had Tahfidz Yanbu'ul Qur'an, Al-Qur'an Dan Terjemahnya (Kudus: CV. Mubarokatan Toyyibah, 2014), 47. 
"Barangsiapa yang melakukan (salaf) salam hendaknya ia melakukan dengan takaran yang jelas untuk jangka waktu yang diketahui." 11

Sementara landasar hukum dari aspek yurisprudensi yang mengatur tentang jual beli salam meliputi:

a) Fatwa Dewan Syariah Nasional diatur pada Fatwa DSN-MUI NO: 05/DSNMUI/IV/2000 Tentang Jual Beli Salam. ${ }^{12}$ Fatwa tersebut menetapkan enam poin yaitu dari ketentuan pembayaran, ketentuan tentang barang, ketentuan tentang salam paralel, penyerahan barang sebelum atau pada waktunya, pembatalan kontrak dan perselisihan.

b) Kompilasi Hukum Ekonomi Syariah terdapat pada buku II, menetapkan ketentuan dari definisi akad salam, kejelasan dan sepsifikasi barang, waktu, tempat penyerahan barang dan pembayaran.

c) Fatwa DSN-MUI Nomor: 34/DsnMui/Ix/2002 Tentang Letter of Credit (L/C) Impor Syari'ah. ${ }^{13}$ Impor syariah dalam fatwa DSN-MUI terserbut adalah surat pernyataan akan membayar kepada Eksportir yang diterbitkan oleh Bank untuk kepentingan Importir dengan persyaratan tertentu sesuai dengan prinsip syariah. ${ }^{14}$ Pasal-pasal dalam fatwa impor syariah membahas

${ }^{11}$ Muhammad Ibn Isma'il Ibn Ibrahim Al-Bukhari, Sahih Al-Bukhari, ed. Muhammad Zuhair Ibn Nasir, vol. 1 (Amiriyyah: Dar Tauq al-Najah, 1422), 1422.

12"Fatwa NO: 05/DSN-MUI/IV/2000 Tentang Jual Beli Salam" (Jakarta: Dewan Syariah Nasional MUI, 2000), http://mui.or.id/wp-content/uploads/files/ fatwa/05-Salam.pdf.

13"Fatwa DSN-MUI Nomor: 34/DSN-MUI/ LX/2002 Tentang Letter Of Credit (L/C) Impor Syari'ah" (Jakarta: Majelis Ulama Indonesia, 2002), http://mui. or.id/wp-content/uploads/files/fatwa/34-LC_Impor.pdf.

14"Fatwa DSN-MUI Nomor: 34/DSN-MUI/ LX/2002 Tentang Letter Of Credit (L/C) Impor Syari’ah.” tentang akad yang digunakan dalam menjalankan transaksi yaitu menggunakan akad-akad wakalah bil ujrah, qardh, murabahah, salam atau istishna', mudharabah, musyarakah, dan hawalah.

d) Peraturan Menteri Perdagangan Republik Indonesia Nomor 40 Tahun 2020 Tentang Ketentuan Penggunaan Angkutan Laut Nasional dan Asuransi Nasional Untuk Ekspor dan Impor Barang Tertentu. ${ }^{15}$

e) Peraturan Presiden Nomor 99 tahun 2020 tentang Pengadaan Vaksin dan Pelaksanaan Vaksinasi Dalam Rangka Penanggulangan Pandemi Corona Virus Disease (Covid) 2019. ${ }^{16}$

f) Peraturan Presiden Republik Indonesia Nomor 14 Tahun 2020 Tentang Perubahan Atas Peraturan Presiden Nomor 99 Tahun 2020 Tentang Pengadaan Vaksin Dan Pelaksanaan Vaksinasi Dalam Rangka Penanggulangan Pandemi. ${ }^{17}$

3. Rukun dan syarat akad jual beli salam

Rukun akad jual beli salam memiliki empat rukun yaitu, pertama Șighat dalam akad jual beli salam terdiri dari ijab dan Kabul dengan menunjukan makna transaksi dengan system jual beli salam. Kedua 'Aqidain dalam akad jual beli salam

15"Permendag No. 40 Tahun 2020 Tentang Ketentuan Penggunaan Angkutan Laut Nasional Dan Asuransi Nasional Untuk Ekspor Dan Impor Barang Tertentu" (Jakarta: BPK RI, 2020), 1, https://peraturan. bpk.go.id/Home/Details/160260/permendag-no-40tahun-2020.

16“PERPRES No. 99 Tahun 2020 Tentang Pengadaan Vaksin Dan Pelaksanaan Vaksinasi Dalam Rangka Penanggulangan Pandemi Corona Virus Disease 2019 (Covid-19)" (Jakarta: BPK RI, 2020), 1, https:// peraturan.bpk.go.id/Home/Details/147944/perpres-no99-tahun-2020.

${ }^{17}$ Peraturan Presiden Republik Indonesia Nomor 14 Tahun 2020 Tentang Perubahan Atas Peraturan Presiden Nomor 99 Tahun 2020 Tentang Pengadaan Vaksin Dan Pelaksanaan Vaksinasi Dalam Rangka Penanggulangan Pandemi 
meliputi para pihak yang baik pemesan maupun pembeli. Ketiga ra's al-mō $l$ adalah harga dari pihak penjual/ pengadaan barang yang harus dibayarkan di muka oleh pihak pembeli. Keempat muslam fih adalah barang pesanan yang menjadi tanggungan pihak yang mengadakan barang. ${ }^{18}$

Adapun Syarat-syarat akad jual beli salam meliputi beberapa hal berikut, Pertama, syarat-sayarat dari sighat (ijabkabul) meliputi, ijab-kabul disebutkan secara jelas dan spesifik oleh para pihak, jabkabul harus sesuai dengan harga maupun sepsifikasi barang yang disepakati oleh para pihak, ketika melakukan ijab-kabul ditentukan waktu saat serah terima barang, ijab-kabul tidak diperbolehkan mengandung sesuatu yang bersifat menggantungkan keabsahan transaksi terhadap kejadian barang pada saat serah terima, ijab-kabul tidak boleh mengandung khiya syarat jadi harus pasti dan jelas. Kedua, 'aqidain baik pembeli maupun pemesan barang memiliki syarat-syarat harus cakap hukum dan tidak dalam dibawah tekanan maupun terpaksa karena 'aqadain harus dalam keadaan suka rela. Ketiga, ra's al-mōl memiliki syarat-syarat sebagai berikut, hukum awal mengenai pembayaran harus dalam bentuk tunai, modal harus dalam bentuk tunai, tidak diperbolehkan dalam bentuk hutang karena akan mengakibatkan jual beli hutang dengan hutang. Pembayaran akad salam untuk mencegah terjadi riba pembayaran salam tidak boleh berbentuk pembebasan hutang yang harus dibayar oleh penjual/ penerima pesanan. Keempat, muslam fì atau barang yang dipesan memiliki syaratsyarat sebagai berikut, barang yang dipesan harus ditentukan dengan sifat-sifat tertentu, jenis, kualitas dan jumlahnya, barang yang dipesan harus bias diidentifikasi secara

${ }^{18}$ Tim Laskar Pelangi, Metodologi Fiqih Muamalah (Lirboyo: Lirboyo Press, 2013), 89. jelas untuk mengurangi kesalahan akibat kurangnya pengetahuan tentang macam barang tersebut, tentang klasifikasi kualitas serta mengenai jumlahnya, penyerahan barang dilakukan di kemudian hari, tempat penyerahan barang harus disepakati oleh pihak-pihak yang berakad, ulama melarang penggantian barang yang dipesan dengan barang lainnya, penggantian ini tidak diperkenankan, karena meskipun belum diserahkan barang tersebut tidak lagi milik muslam alaih, tetapi sudah milik pemesan, apabila barang tersebut diganti dengan barang yang memiliki spesifikasi dan kualitas sama meskipun sumbernya berbeda, para ulama membolehkannya., barang pesanan harus satu jenis tidak dapat dicampur dengan jenis yang lain, barang yang halal/ sahdi perbolehkan di perjual belikan.

\section{Vaksin Covid-19}

Vaksin Covid-19 merupakan vaksin yang masih dalam proses finalisasi yaitu di tahap uji klinis fase tiga. Dalam pembuatan vaksin harus melalui tiga fase uji klinis, yaitu: ${ }^{19}$

1. Uji klinik fase I, dilakukan uji keamanan dan imunogenisitas vaksin pada beberapa yang orang yang berisiko rendah untuk menguji tolerabilitas terhadap vaksin.

2. Uji klinik fase II, memantau keamanan vaksin yaitu berpotensi munculnya efek samping, respon imun, menentukan dosis optimal dan jadwal pemberian vaksinasi.

3. Uji klinik fase III, dalam fase ini untuk melihat efikasi vaksin dalam pencegahan penyakit yang ditargetkan dan pengamatan lebih jauh tentang keamanan vaksin pada

${ }^{19}$ KPCPEN (komite Penanganan COVID-19 dan Pemulihan Ekonomi Nasional), "Paket Advokasi Vaksinasi COVID-19" (Jakarta: Kementrian Kesehatan Republik Indonesia, January 2021), https://Covid19.go.id/ storage/app/media/Materi\%20Edukasi/2021/Januari/ paket-advokasi-vaksinasi-Covid-19-16f08012021 small. pdf. 
populasi yang lebih beragam dan dalam rentang waktu yang panjang. Setelah melalui tiga fase ini vaksin masih perlu menunggu ijin BPOM (Badan Pengawas Obat dan Makanan) seteleh mendapat ijin vaksin dapat didistribusikan pada masyarakat.

Ada dua strategi desain utama untuk pengembangan vaksin virus Covid-19, pertama penggunaan seluruh virus atau antigen vaksin yang direkayasa secara genetik yang dapat dikirimkanmelalui formatyang berbeda. Seluruh vaksin virus termasuk vaksin yang dilemahkan atau dilemahkan. Kedua vaksin SARS hidup yang dilemahkan memutasi eksoribonuklease dan menyelubungi protein untuk mengurangi virulensi dan / atau kemampuan replikasi SARS-CoV. Secara keseluruhan, seluruh vaksin virus dapat memicu respon kekebalan yang kuat dan melindungi dari infeksi virus corona. Vaksin rekayasa genetika yang menargetkan protein virus corona tertentu sering digunakan untuk meningkatkan keamanan dan kemanjuran vaksin. Antigen corona virus seperti protein $\mathrm{S}$, protein $\mathrm{N}$, dan protein $\mathrm{M}$ dapat dikirimkan sebagai vaksin DNA rekombinan dan vaksin vektor virus. ${ }^{20}$

Penetapan jenis-jenis vaksin Covid-19 di Indonesia oleh Kementrian Kesehatan dengan mengeluarkan Surat Keputusan Menteri Kesehatan Nomor H.K.01.07/ Menkes/9860/2020 tentang Penetapan Jenis Vaksin untuk pelaksanan vaksinasi Covid-19, meliputi:

\section{1) AstraZeneca}

Vaksin Covid-19 AstraZeneca adalah larutan injeksi dalam wadah multi dosis (ChAdOx1-S (rekombinan)) dan larutan tidak berwarna sampai agak coklat, bening sampai agak buram. Khasiat klinis Vaksin

${ }^{20}$ Edison Ong et al., "COVID-19 Coronavirus Vaccine Design Using Reverse Vaccinology and Machine Learning," Frontiers in Immunology 11 (2020): 3, https:// doi.org/10.3389/fimmu.2020.01581.
Covid-19 AstraZeneca telah dievaluasi berdasarkan analisis sementara atas data yang dikumpulkan dari empat uji coba acak, buta, terkontrol yang sedang berlangsung. ${ }^{21}$

Harga impor vaksin Covid-19 AstraZeneca sebesar 60.000 rupiah per dosis dan Indonesia telah membayar 50 persen untuk 100 juta dosis sebesar 3,6 triliun. $^{22}$

2) China National Pharmaceutical Group Corporation (Sinopharm)

Vaksin Covid-19 Sinopharm menggunakan metode inaktivasi virus, metode ini merupakan cara klasik untuk memproduksi vaksin yaitu, virus yang terbunuh masih bersifat imunogenik. Ini dapat diidentifikasi oleh system kekebalan tubuh manusia, memicu respon kekebalan dan dengan demikian menghasilkan antibodi. Vaksin Covid-19 CNBG Sinopharm berasal dari sel Vero yang melalui proses budidaya, inaktivasi dan pemurnian. Imunogenisitas, keamanan, dan perlindungan kekebalan vaksin dipelajari dengan serangkaian tes pada hewan seperti tikus, marmut, kelinci dan monyet rhesus.

Vaksin COVID-19 CNBG Sinopharm diumumkan secara resmi terdaftar di UEA dan Bahrain masing-masing pada tanggal 9 dan 12 Desember, berdasarkan hasil uji klinis Tahap III yang menunjukkan tingkat kemanjuran $86 \%$, tingkat serokonversi $99 \%$ dari anti bodi penawar dan Efektivitas 100\% dalam mencegah

21"Coronavirus » Information Leaflet for UK Recipients of COVID-19 Vaccine AstraZeneca," accessed February 25, 2021, https://www.england.nhs. $\mathrm{uk} /$ coronavirus/publication/information-leaflet-forrecipients-of-Covid-19-vaccine-astrazeneca/.

${ }^{22}$ C. N. N. Indonesia, "Intip Ongkos yang Dibayar RI untuk Vaksin AstraZeneca," ekonomi, accessed May 20, 2021, https://www.cnnindonesia.com/ ekonomi/20210316104046-92-617958/intip-ongkosyang-dibayar-ri-untuk-vaksin-astrazeneca. 
kasus Covid-19 sedang dan berat. Karena standar diagnosis kasus infeksi dan proses peninjauan uji klinis Fase III bervariasi di berbagai negara, tingkat kemanjuran $86 \%$ yang diumumkan oleh UEA dan 79,34\% oleh Cina adalah nyata dan valid. ${ }^{23}$ Harga impor vaksin Covid-19 Sinopharmsebesar 2,1 juta rupiah per dosis. ${ }^{24}$

3) Moderna

Vaksin Covid-19 Moderna adalah vaksin mRNA yang telah terbukti sangat efektif dalam mencegah gejala penyakit Covid-19. Secara keseluruhan, dalam fase 3 uji coba acak, terstratifikasi, tersamar ganda, terkontrol plasebo ini, mRNA1273 efektif mencegah penyakit Covid-19 bergejala dan aman pada waktu median untuk tindak lanjut selama 2 bulan. ${ }^{25}$ Harga impor vaksin Covid-19 moderna sebesar 450.000 ribu per dosis. ${ }^{26}$

4) Pfizer

Vaksin Pfizer BioNTech Covid-19 adalah vaksin messenger RNA (mRNA) yang memiliki komponen sintetis, atau yang diproduksi secara kimiawi, dan komponen yang diproduksi secara enzimatik dari zat yang ada secara alami seperti protein. Vaksin tidak mengandung virus hidup. ${ }^{27}$ Pembuatan vaksin ini tidak seperti

23“China Grants Conditional Market Approval for Sinopharm CNBG's COVID-19 Vaccine_HOME," accessed May 20, 2021, http:/www.sinopharm.com/ en/s/1395-4173-38862.html.

${ }^{24}$ Khadijah Nur Azizah, "Segini Harga Vaksin COVID-19 Buatan Luar Negeri, Mana yang Paling Murah?," detikHealth, accessed May 20, 2021, https:// health.detik.com/berita-detikhealth/d-5250339/seginiharga-vaksin-Covid-19-buatan-luar-negeri-mana-yangpaling-murah.

${ }^{25}$ Selebihnya lihat, "Moderna COVID-19 Vaccine", dalam"COVID-19 Real Time Learning Network," accessed May 20, 2021, https://www. idsociety.org/Covid-19-real-time-learning-network/.

${ }^{26}$ Azizah, "Segini Harga Vaksin COVID-19 Buatan Luar Negeri, Mana yang Paling Murah?"

27"The Facts About Pfizer and BioNTech's COVID-19 Vaccine | Pfizer," accessed February 24, vaksin tradisional yang menggunakan virus yang tidak aktif, mati, atau bagian dari virus sebenarnya untuk memacu respon imun tetapi mRNA mengirimkan pesan ke sel tubuh melalui amplop nano partikel lipid yang menginstruksikan sel untuk menghasilkan protein lonjakan yang ditemukan di permukaan virus corona yang memulai infeksi. Proses menginstruksikan sel adalah untuk menghasilkan protein lonjakan memacu respon imun, termasuk pembentukan anti bodi khusus untuk protein lonjakan SARS-CoV-2.Vaksin Pfizer akan dihargai US\$19,50 (Rp 276,050) per dosis. ${ }^{28}$

5) Bio Farma (Persero)

Vaksin Covid-19 oleh PT. Bio Farma adalah produk vaksin dalam negeri yang di produksi oleh PT. Bio Farma. Vaksin Covid-19 dalam negeri dinamakan vaksin merah putih dengan proses produksi kerjasama dengan perusahaan asal ChinaSinovac Biotech. Kerjasama dalam hal ini adalah pengadaan bahan baku serta ahli teknologi dari pihak perusahaan ChinaSinovac Biotech untuk fill and finish product Covid-19 dan proses quality control sebelum pengolahan bahan baku. ${ }^{29}$ Harga bahan baku vaksin dari sinovac saat impor vaksin 157.000 rupiah per dosisi. ${ }^{30}$

2021, https://www.pfizer.com/news/hot-topics/the facts_about_pfizer_and_biontech_s_Covid_19_vaccine.

${ }^{28}$ Liputan6.com, "Pfizer hingga Sinovac, Daftar Harga 10 Vaksin COVID-19 Tahap 3 di Dunia," liputan6. com, December 13, 2020, https://www.liputan6.com/ global/read/4431821/pfizer-hingga-sinovac-daftarharga-10-vaksin-covid-19-tahap-3-di-dunia.

${ }^{29}$ M. Nursyamsi, "Bio Farma Siap Olah Bahan Baku Vaksin Covid-19 | Republika Online," accessed February 17, 2021, https://www.republika.co.id/berita/ qmupjg370/bio-farma-siap-olah-bahan-baku-vaksincovid19.

${ }^{30}$ Widiarsi Agustina, “Terungkap, Indonesia Punya Media Massa Terbanyak Di Dunia," Tempo, February 10, 2018, https://nasional.tempo.co/read/1059285/ terungkap-indonesia-punya-media-massa-terbanyak-didunia. 
6) Sinovac Biotech Ltd

Vaksin Sinovac Biotech Ltd didasarkan pada patogen tidak aktif yang dibuat dengan menumbuhkan seluruh virus di laboratorium dan kemudian membunuhnya. CoronaVac (Sinovac Life Sciences, Beijing, China) adalah kandidat vaksin yang tidak aktif terhadap Covid-19 yang telah menunjukkan imunogenisitas yang baik pada tikus dan primata nonmanusia dengan antibody penawar yang diinduksi vaksin terhadap SARS-CoV-2, yang dapat menetralkan sepuluh strain representatif SARS-CoV-2.15.

Selain itu, hasil menunjukkan CoronaVac memberikan perlindungan parsial atau lengkap pada keradari pneumonia interstisial yang parah setelah tantangan SARS-CoV-2, tanpa peningkatan infeksi yang bergantung pada antibodi yang dapat diamati, yang mendukung perkembangan ke uji klinis pada manusia. ${ }^{31}$ Harga impor vaksin Covid-19 sinovac di Indonesia memiliki perbedaan harga antara vaksin dan bahan baku vaksin. Bahan baku vaksin sinovac 157.000 rupian per dosis dan vaksin jadi 192.000 ribu per dosis. ${ }^{32}$

\section{Legalitas Impor Vaksin Covid-19}

Penggunaan vaksin di Indonesia harus mendapat izin dari Badan Pengawas Obat dan Makanan (BPOM) dan sertifikasi jaminan produk halal dari Dewan Syariah Nasional Majelis Ulama Indonesia (DSN-MUI). Dari jenis-jenis vaksin Covid-19 yang sudah

${ }^{31}$ Yanjun Zhang et al., "Safety, Tolerability, and Immunogenicity of an Inactivated SARS-CoV-2 Vaccine in Healthy Adults Aged 18-59 Years: A Randomised, Double-Blind, Placebo-Controlled, Phase 1/2 Clinical Trial," The Lancet Infectious Diseases 21, no. 2 (February 1, 2021): 181-92, https://doi.org/10.1016/ S1473-3099(20)30843-4.

${ }^{32}$ Agustina, “Terungkap, Indonesia Punya Media Massa Terbanyak Di Dunia." ditetapkan oleh kementerian kesehatan, Indonesia baru mendatangkan vaksin sinovac. Vaksin sinovac mendapat ijin penggunaan darurat oleh BPOM dan sertifikasi kehalalan produk oleh Majelis Ulama Indonesia tertera pada fatwa Majelis Ulama Indonesia Nomor: 02 Tahun 2021 Tentang Produk Vaksin Covid-19 Dari Sinovac Life Sciences Co. Ltd. China Dan Pt. Bio Farma (Persero). ${ }^{33}$ Di dalam fatwa memberikan ketentuan hukum sebagai berikut:

1. Vaksin Covid-19 produksi Sinovac Life Sciences Co. Ltd. China dan PT. Bio Farma (Persero) hukumnya suci dan halal.

2. Vaksin Covid-19 produksi Sinovac Life Sciences Co. Ltd. China dan PT. Bio Farma (Persero) sebagaimana angka 1 boleh digunakan untuk umat Islam sepanjang terjamin keamanannya menurut ahli yang kredibel dan kompeten.

Selain fatwa MUI dalam kaidah fikih dijelaskan darurat harus dihilangkan untuk kemaslahatan. Maslahah menurut al-sytaibi dibagi menjadi lima yaitu: hifz al-din (perlindungan agama), hifz al-nafs (perlindungan jiwa), hifz al-'aql (perlindungan akal), hifz al-nasl (perlindungan keturunan/ keluarga), dan hifz al-maal (perlindungan kepemilikan harta).

Vaksin Covid-19 yang akan di gunakan di Indonesia telah ditetapkan oleh Kementerian Kesehatan yaitu dengan diedarkan Surat Keputusan Menteri Kesehatan Nomor H.K.01.07/Menkes/9860/2020 tentang Penetapan Jenis Vaksin untuk pelaksanan vaksinasi Covid-19, yaitu PT. Bio Farma (Persero), AstraZeneca, China National Pharmaceutical Group Corporation (Sinopharm), Moderna, Pfizer Inc dan

33"Fatwa MUI No 02 Tahun 2021 Tentang Produk Vaksin Covid-19 Dari Sinovac Life Sciences, Co. Ltd China Dan PT Biofarma," Majelis Ulama Indonesia, January 20, 2021, https://mui.or.id/produk/fatwa/29485/ fatwa-mui-no-02-tahun-2021-tentang-produk-vaksinCovid-19-dari-sinovac-life-sciences-co-ltd-china-danpt-biofarma/. 
BioNTech dan Sinovac Biotech Ltd. Wewenang kementrian kesehatan ini berdasarkan Peraturan Presiden No. 99 tahun 2020 tentang Pengadaan Vaksin dan Pelaksanaan Vaksinasi dalam Rangka Penanggulangan Pandemi Covid-19. Pengadaan vaksin Indonesia melakukan kerjasama Internasional oleh kementrian luar negeri dengan berkoordinasi dengan kementrian kesehatan atas jenis dan jumlah pengadaan vaksin Covid-19.

Peraturan presiden mengatur pengadaan vaksin dengan melakukan pembayaran dimuka atau dapat diberikan uang muka yang dituangkan dalam kontrak atau perjanjian. Mekanisme pembayaran pengadaan vaksin Covid-19 yang diatur oleh pemerintah jika ditinjau dari hukum ekonomi syariah termasuk dalam akad jual beli salam. Akad jual beli salam adalah modal diserahkan terlebih dahulu, sedangkan barang yang dibeli diserahkan setelah tenggat waktu tertentu dengan menyebutkan spesifikasi barang, waktu dan tempat penyerahan. Keabsahan dari akad jual beli salam harus memenuhi rukun dan syarat-syaratnya. Hal ini berkaitan dengan akad salam pengadaan vaksin Covid-19, jenisjenis vaksin Covid-19 yang dditetapkan oleh kementrian kesehatan ada syarat yang belum terpenuhi. Penandatangan perjanjian pengadaan vaksin Covid-19 belum diketahui jenis vaksin Covid-19 di Indonesia belum diketahui kehalalan maupun keefektifitasnya. Sedangkan dalam syarat akad jual beli salam barang atau muslam fì harus spesifik dari jenis, kualitas, jumlahnya, harus bisa diidentifikasi secara jelas untuk mengurangi kesalahan akibat kurangnya pengetahuan tentang macam barang tersebut dan hanya barang yang halal/ sah diperbolehkan diperjualbelikan.

Mekanisme dalam pengadaan vaksin Covid-19 di Indonesia yaitu setelah penandatangan perjanjian dan pembayaran dimuka baru vaksin tiba di Indonesia kemudian proses uji kandungan vaksin oleh Badan POM.
Setelah diuji oleh Badan POM dan diketahui kandungan dalam vaksin Covid-19 aman kemudian dikeluarkan izin penggunaan darurat, pihak ulama Indonesia melakukan audit oleh tim LPPOM MUI kemudiaan dikeluarkan fatwa kehalalan vaksin Covid-19. Proses audit dari pihak BPOM dan Pihak MUI dalam mengeluarkan izin pemakaian vaksin dan fatwa tentang vaksin Covid-19 tidak berlaku untuk semua jenis yang telah ditetapkan oleh kementrian kesehatan. Kehalalan vaksin Covid-19 yang ditetapkan oleh MUI hanya berlaku untuk jenis vaksin yang telah mendapatkan pernyataan vaksin tersebut aman dan tidak mengandung bahan haram oleh Badan POM. Saat ini di Indonesia vaksin yang telah ditetapkan kehalalan dan mendapat izin penggunaan darurat yaitu jenis vaksin sinovach dan produksi dari PT. Bio Farma (Persero).

Jaminan kepastian keamanan terhadap vaksin Covid-19 dan jaminan halal produk dan thayib, vaksin Covid-19 yang dikeluarkan oleh pihak Badan POM dan MUI menjadikan akad salam sah karena pada tahap ini telah dipenuhi syarat barang dalam akad salam. Jika terjadi keadaan force majeur atau keadaan kahar yaitu jika terjadi keadaan diluar para pihak dalam kontrak atau kerjasama dan tidak dapat diperkiraan sebelumnya, sehingga kewajiban yang ditentukan dalam kontrak atau kerjasama tidak dapat dipenuhi dari seluruh proses pengadaan vasin sampai dengan pemberian persetujuan pemakaian darurat vaksin Covid-19 maka akad dapat di perbaharui atau diberhentikan dan jika terjadi perselisihan dapat diselesaikan melalui arbitrase sesaui dengan ketetnuan Peraturan Presiden. Proses vaksinasi merupakan bagian dari usaha pemerintah untuk menanggulangi pandemi Covid-19, karena pandemi ini telah memakan korban jiwa dan mengancam jiwa penduduk Indonesia lainnya. 


\section{Perspektif Maqashid Syariah}

Maqashid syariah merupakan istilah gabungan dari dua kata maqashid dan syariah. Maqashid adalah bentuk plural dari maqsud, qasd, maqsid atau qusud yang merupakan derivasi dari kata kerja qasada yaqsudu, dengan beragam makna seperti menuju suatu arah, tujuan, tengah-tengah, adil dan tidak melampaui batas, jalan lurus, tengah-tengah antara berlebihlebihan dan kekurangan. Syariah, secara etimologi bermakna jalan menuju mata air, jalan menuju mata air ini dapat pula dikatakan sebagai jalan kearah sumber pokok kehidupan. Syariah secara terminologi adalah al nusus al muqaddasah (teks-teks suci) dari al Quran dan al Sunnah yang mutawatir yang sama sekali belum dicampuri oleh pemikiran manusia. Menurut Ibnu Ashur, maqhasid syariah dibagi menjadi dua yaitu pertama, maqashid al tashri' al ammah adalah makna-makna dan hikmah yang tersembunyi pada seluruh atau mayoritas hukum, yang mana subtansi hukum tersebut tidak terikat ruang hukum secara khusus. Kedua, maqhasid al khasah adalah cara-cara yang dikehendaki shari' untuk merealisasikan kemanfaatan manusia, atau untuk menjaga kemaslahatan umum dalam amal perbuatan yang khusus. ${ }^{34}$ Sedangkan Wahbah al-Zuhaili mendefinisikan maqashid syari'ah dengan makna-makna dan tujuan-tujuan yang dipelihara oleh syara' dalam seluruh hukumnya, atau tujuan akhir dari syari'at dan rahasiarahasia yang diletakkan oleh syara' pada setiap hukumnya.

Tujuan disyariatkan hukum adalah untuk mnciptakan kemashlahatan manusia, baik secara individu maupun kolektif dalam masyarakat. kemaslahatan yang dimaksud dalam hukum Islam adalah kemaslahatan yang sejati, bukan kemaslahatan yang semu yang dipengaruhi nafsu belaka. Kemaslahatan disini meliputi

${ }^{34}$ Moh. Toriquddin, Teori Maqashid Syariah Perspektif Ibnu Ashur, Ulul Albab Volume 14, no.2 Tahun 2013, 195. kemaslahatan jasmani dan kemaslahatan rohani atau spiritual. Kemaslahatan yang ditunjuk hukum Islam adalah kemaslahatan di dunia dan di akhirat bukan semata mata dunia. Kemaslahatan yang menjadi orientasi syariah didasarkan pada lima prinsip kepentingan manusia yang disebut dengan al-mabdi'alkhamsah atau al-ușũl al-khamsah meliputi: menjaga agama (hifz al-din), menjaga jiwa (hifz al-nafs), menjaga akal (hifz al-'aql), menjaga harta (hifz al-mal), dan menjaga keturunan (hifz al-nasl). Implementasi dari menjaga jiwa (hifz al-nafs) dalam pandemi Covid-19 yaitu dengan vaksinasi vaksin Covid-19.

Upaya vaksinasi bagian dari meraih kemaslahatan dengan menolak mudarat, yaitu untuk melindungi jiwa bentuk dari maslahah daruriyat yaitu sesuatu yang harus ada menjadi hal eksistensi kehidupan manusia. Dalam hal ini legalitas vaksin Covid-19 dengan diterbitkan fatwa MUI untuk kehalalan produk vaksin, pihak Badan POM mengeluarkan keamanan penggunaan produk vaksin Covid-19 dan sanksi dari pemerintah jika terdaftar sebagai sasaran penerima vaksin tidak mengikuti vaksinasi Covid-19 dalam implementasi maqashid syariah. Maqashid syariah dalam hal ini bagian dari maqashid al khasah yaitu tujuan khusus dimana cara-cara yang dikehendaki shari' untuk merealisasikan kemanfaatan manusia, atau untuk menjaga kemaslahatan umum. Hal ini dalam amal perbuatan yang khusus adalah hifž al-nafs (melindungi jiwa), melindungi jiwa/ diri dari tertularnya Covid-19 dan menekan tingginya angka positif di Indonesia.

\section{PENUTUP}

Legalitas dalam impor vaksin menurut hukum ekonomi syariah menggunakan akad jual beli salam. Mekanisme akad jual beli salam vaksin Covid-19 dengan sistem kerjasama Internasional mempengaruhi legalitas hukum dalam hal ini keabsahan akad. Keabsahan 
suatu akad bila terpenuhinya rukun dan syaratsyaratnya. Melalui Majelis Ulama Indonesia (MUI) memberi ketetapan bahwa produk vaksin yang telah melewati uji dari Badan POM dengan memastikan kandungan vaksin Covid-19 tidak mengandung bahan haram sehingga vaksin Covid-19 halal dan baik. Apabila terdapat force majeur dalam proses pengadaan vaksin maupun vaksinasi kerjasama dapat dibatalkan. Sementara legalitas dalam impor vaksin Covid-19 dalam implementasi maqashid syariah adalah bagian dari maqashid al khasah yaitu tujuan khusus dimana cara-cara yang dikehendaki shari' untuk merealisasikan kemanfaatan manusia, atau untuk menjaga kemaslahatan umum dalam amal perbuatan yang khusus dalam hal ini hifz al-nafs (melindungi jiwa). Impor vaksin sebagai bentuk upaya pemerintah dalam menanggulangi pandemi Covid-19 yaitu untuk melindungi jiwa masyarakat Indonesia yang terancam terpapar virus Covid-19 dalam maqashid syariah guna mencapai tujuan yang disyariatkan hukum untuk kemashlahatan manusia, baik secara individu maupun kolektif dalam masyarakat.

\section{DAFTAR PUSTAKA}

Agustina, Widiarsi. "Terungkap, Indonesia Punya Media Massa Terbanyak Di Dunia." Tempo, February 10, 2018. https://nasional.tempo.co/read/1059285/ terungkap-indonesia-punya-mediamassa-terbanyak-di-dunia.

Al-Bukhari, Muhammad Ibn Isma'il Ibn Ibrahim. Sahih Al-Bukhari. Edited by Muhammad Zuhair Ibn Nasir. Vol. 2. Amiriyyah: Dar Tauq al-Najah, 1422.

Azizah, Khadijah Nur. "Segini Harga Vaksin COVID-19 Buatan Luar Negeri, Mana yang Paling Murah?" detikHealth. Accessed May 20, 2021. https://health. detik.com/berita-detikhealth/d-5250339/ segini-harga-vaksin-covid-19-buatanluar-negeri-mana-yang-paling-murah.

Az-Zuhaili, Wahbah. Fiqih Islam Wa Adillatuhu. Jakarta: Gema Insani, 2011.

"China Grants Conditional Market Approval for Sinopharm CNBG's COVID-19 Vaccine HOME_国药党建网." Accessed May 20, 2021. http://www.sinopharm.com/ en/s/1395-4173-38862.html.

"Coronavirus » Information Leaflet for UK Recipients of COVID-19 Vaccine AstraZeneca." Accessed February 25, 2021. https://www.england.nhs.uk/ coronavirus/publication/informationleaflet-for-recipients-of-covid-19vaccine-astrazeneca/.

"COVID-19 Real Time Learning Network." Accessed May 20, 2021. https://www. idsociety.org/covid-19-real-timelearning-network/.

"Fatwa DSN-MUI Nomor: 34/DSN-MUI/ LX/2002 Tentang Letter Of Credit (L/C) Impor Syari'ah.” Jakarta: Majelis Ulama Indonesia, 2002. http://mui.or.id/ wp-content/uploads/files/fatwa/34-LC_ Impor.pdf.

Majelis Ulama Indonesia. "Fatwa MUI No 02 Tahun 2021 Tentang Produk Vaksin Covid-19 Dari Sinovac Life Sciences, Co. Ltd China Dan PT Biofarma," January 20, 2021. https://mui.or.id/produk/ fatwa/29485/fatwa-mui-no-02-tahun2021-tentang-produk-vaksin-covid-19dari-sinovac-life-sciences-co-ltd-chinadan-pt-biofarma/.

"Fatwa NO: 05/DSN-MUI/IV/2000 Tentang Jual Beli Salam.” Jakarta: Dewan Syariah Nasional MUI, 2000. http://mui.or.id/wpcontent/uploads/files/fatwa/05-Salam. pdf.

Hafidzi, Anwar. "Penggunaan Vaksin: Antara Legalitas Dan Formalitas Perspektif 
Maqashid Al-Syariah.” Yudisia : Jurnal Pemikiran Hukum Dan Hukum Islam 11, no. 2 (Desember 2020).

Hariyanto, Hariyanto. "Hubungan Kewenangan Antara Pemerintah Pusat Dan Pemerintah Daerah Berdasarkan Negara Kesatuan Republik Indonesia." Volksgeist: Jurnal Ilmu Hukum Dan Konstitusi 3, no. 2 (December 29, 2020): 99-115. https:// doi.org/10.24090/volksgeist.v3i2.4184.

Hasan, Iqbal. Analisis Data Penelitian Dengan Statistik. Jakarta: PT. Bumi Aksara, 2006.

Heaton, Penny M. "The Covid-19 VaccineDevelopment Multiverse." The New England Journal of Medicine 383, no. 20 (November 12, 2020): 1986-88. https:// doi.org/10.1056/NEJMe2025111.

Indonesia, C. N. N. "Intip Ongkos yang Dibayar RI untuk Vaksin AstraZeneca." ekonomi. Accessed May 20, 2021. https://www.cnnindonesia.com/ ekonomi/20210316104046-92-617958/ intip-ongkos-yang-dibayar-ri-untukvaksin-astrazeneca.

Kompilas Hukum Ekonomi Syari'ah. Jakarta: Mahkamah Agung RI, 2011. https:// perpustakaan.mahkamahagung.go.id/ assets/resource/ebook/02.pdf.

Liputan6.com. "Pfizer hingga Sinovac, Daftar Harga 10 Vaksin COVID-19 Tahap 3 di Dunia." liputan6.com, December 13, 2020. https://www.liputan6.com/global/ $\mathrm{read} / 4431821 /$ pfizer-hingga-sinovacdaftar-harga-10-vaksin-covid-19-tahap3-di-dunia.

M. Nursyamsi. "Bio Farma Siap Olah Bahan Baku Vaksin Covid-19 | Republika Online." Accessed February 17, 2021. https://www.republika.co.id/berita/ qmupjg370/bio-farma-siap-olah-bahanbaku-vaksin-covid19.

Ma'had Tahfidz Yanbu'ul Qur'an. AlQur'an Dan Terjemahnya. Kudus: CV. Mubarokatan Toyyibah, 2014.
Mahmud Nasution, Muhammad. "Vaksinasi Dalam Perspektif Islam." Forum Paedagogik 9, no. 2 (2018): 61-70. https://doi.org/10.24952/paedagogik. v10i2.2818.

Ong, Edison, Mei U. Wong, Anthony Huffman, and Yongqun He. "COVID-19 Coronavirus Vaccine Design Using Reverse Vaccinology and Machine Learning." Frontiers in Immunology 11 (2020). https://doi.org/10.3389/ fimmu.2020.01581.

"Paket Advokasi Vaksinasi COVID-19." Jakarta: Kementrian Kesehatan Republik Indonesia, January 2021. https://covid19. go.id/storage/app/media/Materi\%20 Edukasi/2021/Januari/paket-advokasivaksinasi-covid-19-16f08012021small. pdf.

"Permendag No. 40 Tahun 2020 Tentang Ketentuan Penggunaan Angkutan Laut Nasional Dan Asuransi Nasional Untuk Ekspor Dan Impor Barang Tertentu." Jakarta: BPK RI, 2020. https://peraturan. bpk.go.id/Home/Details/160260/ permendag-no-40-tahun-2020.

"PERPRES No. 99 Tahun 2020 Tentang Pengadaan Vaksin Dan Pelaksanaan Vaksinasi Dalam Rangka Penanggulangan Pandemi Corona Virus Disease 2019 (Covid-19).” Jakarta: BPK RI, 2020. https://peraturan.bpk.go.id/ Home/Details/147944/perpres-no-99tahun-2020.

S.S Kurniawan. "Terjangkit virus corona tanpa gejala, benar-benar tak merasakan gejala?," September 14, 2020. https:// kesehatan.kontan.co.id/news/terjangkitvirus-corona-tanpa-gejala-benar-benartak-merasakan-gejala.

"The Facts About Pfizer and BioNTech's COVID-19 Vaccine | Pfizer." Accessed February 24, 2021. https://www.pfizer. 
com/news/hot-topics/the_facts_about_ pfizer_and_biontech_s_covid_19_ vaccine.

Tim Laskar Pelangi. Metodologi Fiqih Muamalah. Lirboyo: Lirboyo Press, 2013.

"Vaccination from the Perspective of Islamic Legal Maxim." International Journal of Academic Research in Business and Social Sciences 7, no. 12 (2017).
Zhang, Yanjun, Gang Zeng, Hongxing Pan, Changgui $\mathrm{Li}$, Yaling $\mathrm{Hu}$, Kai Chu, Weixiao Han, et al. "Safety, Tolerability, and Immunogenicity of an Inactivated SARS-CoV-2 Vaccine in Healthy Adults Aged 18-59 Years: A Randomised, Double-Blind, Placebo-Controlled, Phase 1/2 Clinical Trial." The Lancet Infectious Diseases 21, no. 2 (February 1, 2021): 181-92. https://doi.org/10.1016/S14733099(20)30843-4. 